\title{
Estimation of digesta kinetics of different particle size fractions using rumen evacuation technique in dairy cows fed red clover-grass silage ${ }^{*}$
}

\author{
A.R. Bayat ${ }^{1,2}$, M. Rinne ${ }^{1}$, H. Khalili ${ }^{1}$, R. Valizadeh ${ }^{2}$ \\ and P. Huhtanen ${ }^{1,3,4}$ \\ ${ }^{1}$ MTT Agrifood Research Finland, Animal Production Research \\ 31600 Jokioinen, Finland \\ ${ }^{2}$ Animal Science Department, Agricultural Faculty, Ferdowsi University of Mashhad \\ 91775-1163 Mashhad, Iran
}

(Received 22 January 2007; revised version 22 May 2007; accepted 21 November 2007)

\begin{abstract}
Ruminal kinetic parameters of different particle size fractions were estimated using four lactating dairy cows in a $4 \times 4$ Latin square experiment. Cows received red clover-grass silage alone diet. Ruminal contents and faeces were divided into six particle size fractions by wet sieving. Indigestible (iNDF) and potentially digestible (pdNDF) neutral detergent fibre were separated by a $12 \mathrm{~d}$ ruminal in situ incubation. Particles $>2.5 \mathrm{~mm}$ formed the greatest dry matter, iNDF and pdNDF pools in the rumen. Passage rates of iNDF and pdNDF increased with decreasing particle size. Particle breakdown in the rumen was a relatively slow process $\left(0.041 \mathrm{~h}^{-1}\right)$. Contribution of particle breakdown to turnover of different particle size fractions of rumen iNDF decreased with decreasing particle size while the contribution of passage increased. Accumulation of iNDF in the rumen was greater than generally observed with grass-based diets and pdNDF was rapidly digested.
\end{abstract}

KEY WORDS: steady-state model, indigestible NDF, ruminal digesta kinetics, legume, particle breakdown, passage rate

\footnotetext{
* Supported by the Academy of Finland and the Iranian Ministry of Science, Research and Technology

${ }^{3}$ Current address: Department on Animal Science, Cornell University, Ithaca, NY 14853-4801, USA

${ }^{4}$ Corresponding author: e-mail: pekka.huhtanen@mtt.fi
} 


\section{INTRODUCTION}

Most of the variation in forage digestibility in ruminants results from the concentration and digestibility of neutral detergent fibre (NDF) (Huhtanen et al., 2006). Digestion of dietary entities is a time-dependent process; therefore the rate of digestion in relation to the rate of passage is a critical dynamic characteristic affecting digestibility (Mertens, 1993). The rate of cell wall digestion in relation to its passage is slow compared to cell solubles (Van Soest, 1994), which indicates the importance of passage rate (or mean residence time) in models predicting NDF digestibility.

Passage kinetic parameters are generally estimated by labelling feed particles with external markers (Owens and Hanson, 1992; Ellis et al., 1994) such as rare earths (Combs et al., 1992) and chromium mordanted fibre (Udén et al., 1980). Both rare earths (Combs et al., 1992) and chromium mordanted fibre (Ramanzin et al., 1991) have some limitations in estimating passage rate accurately. Internal markers such as ADF-bound ${ }^{15} \mathrm{~N}$ may be used as a reference method (Huhtanen and Hristov, 2001) although it is too laborious for routine use.

Indigestible NDF (iNDF) has been used as an internal marker to estimate passage (Tamminga et al., 1989; Huhtanen and Kukkonen, 1995) and breakdown kinetics of different particle size fractions (Bruining et al., 1998; Rinne et al., 2002; Huhtanen et al., 2007). Since physical breakdown of large particles by mastication during ingestion and rumination is an important part of digestion process in ruminants (Allen and Mertens, 1988; Huhtanen et al., 2006), one of the advantages of using iNDF as a marker along with the rumen evacuation technique is the possibility to study the passage, breakdown and digestion rates of different particle size fractions simultaneously.

Considering the selective retention mechanism of large particles in the reticulo-rumen (Allen and Mertens, 1988), estimating the passage and breakdown kinetics of different particle size fractions can be helpful to assess their restrictive contribution on feed intake. Rumen evacuation technique combined with iNDF determination can be used to estimate the total mean residence time in the rumen. However, passage kinetics can not be described by a single compartment model and distribution of the ruminal mean residence time between the two compartments has at least some influence on the estimated digestibility (Huhtanen et al., 2006).

The objective of this study was to estimate the distribution of ruminal mean residence time between rumen non-escapable and escapable compartments using rumen evacuation technique combined with wet sieving and iNDF determination. Kinetic parameters for different particle size fractions of iNDF and potentially digestible NDF (pdNDF) were estimated using steady-state rumen model. In the present experiment, the cows were fed forage alone diet to avoid confounding 
effects of particles from different dietary components. Milk production, digestion and marker kinetic parameters have been published by Khalili and Huhtanen (2002).

\section{MATERIAL AND METHODS}

Animals, diet, and experimental design

Four Finnish Ayrshire cows in midlactation (164 \pm 8 days in milk) with an average liveweight of $545 \pm 26 \mathrm{~kg}$ and milk production of $20.7 \pm 0.40 \mathrm{~kg}$ during the experiment were used. The cows were in their second lactation and each of them was fitted with a ruminal cannula and a simple T-shape cannula in the proximal duodenum. They were housed individually, fed at 07.00 and had ad libitum access to silage throughout the day. All cows were fed red clover-grass silage in a balanced $4 \times 4$ Latin square design using 14-d periods. The four treatments consisted of casein infusions as follows: control $\left(0 \mathrm{~g} \mathrm{~d}^{-1}\right)$, rumen $\left(300 \mathrm{~g} \mathrm{~d}^{-1}\right)$, duodenum $\left(300 \mathrm{~g} \mathrm{~d}^{-1}\right)$ and rumen and duodenum (300 $\left.+300 \mathrm{~g} \mathrm{~d}^{-1}\right)$. The silage used was prepared from a regrowth of red clover-grass (3:1) sward and ensiled as direct-cut using a formic acid-based additive $\left(800 \mathrm{~g} \mathrm{~kg}^{-1}\right.$ formic acid, $20 \mathrm{~g} \mathrm{~kg}^{-1}$ orthophosphoric acid and $180 \mathrm{~g} \mathrm{~kg}^{-1}$ water) applied at a rate of 5.81 tonne ${ }^{-1}$ fresh matter. The silage dry matter (DM) concentration was $204 \mathrm{~g} \mathrm{~kg}^{-1}$, its $\mathrm{pH}$ was 4.21, and concentrations of ash, nitrogen, NDF and iNDF were 67, 26.9, 457 and $135 \mathrm{~g} \mathrm{~kg}^{-1} \mathrm{DM}$, respectively.

\section{Procedures and chemical analyses}

The total weight of ruminal contents was estimated by emptying the rumen of each cow on two occasions at 06.00 and $09.30 \mathrm{~h}$ on $\mathrm{d} 13$ and 14 of each experimental period according to the procedure described by Khalili and Huhtanen (2002). The average weight of ruminal contents of the two evacuations was used as the estimation of the diurnal mean. Total faecal collection was conducted during $\mathrm{d} 10$ to 12 of each period. Representative faecal samples were taken for further analyses.

The particle size distribution of ruminal digesta (separately for the two sampling times) and faecal samples was determined by the Retsch AS200 Digit wet sieving apparatus (Retsch $\mathrm{GmbH}$, Haan, Germany). The samples were divided into six particle size fractions by wet sieving using sieves with pore sizes of 2.5 , $1.25,0.63,0.315,0.16$ and $0.08 \mathrm{~mm}$. Two replicates $(60 \mathrm{~g})$ of fresh rumen contents and faeces were sieved for 10 min using a water flow of $3.51 \mathrm{~min}^{-1}$. After sieving, the material from each sieve was quantitatively collected to pre-weighed nylon bags (pore size $38 \mu \mathrm{m}$ ), dried at $60^{\circ} \mathrm{C}$ for $48 \mathrm{~h}$ and weighed to determine the DM distribution of different particle size fractions. The mean values of particle 
size distribution obtained from the two rumen evacuation times were used in further calculations. For each rumen evacuation time, one of the replicates was used for NDF and the other for iNDF determination. The samples for iNDF determination (without milling) were incubated for $12 \mathrm{~d}$ in the rumen of one cow fed a forage based diet. The bags for NDF determination were incubated for $1 \mathrm{~h}$ in boiling NDF solution containing $\mathrm{Na}_{2} \mathrm{SO}_{3}$ (Van Soest et al., 1991), rinsed with cold water for 25 min using a household washing machine and dried to a constant weight at $60^{\circ} \mathrm{C}$. The same procedure was used for the nylon bags from iNDF determination after ruminal incubation. Ash is included in all NDF and iNDF values.

\section{Calculations and statistical methods}

The particle size distribution of silage entering the rumen was assumed to be similar to the values measured in another experiment using the same animals which were fed four grass silages of varying maturity (Rinne et al., 2002). The particle size distribution used for ingested silage was $365,156,16,16,47,26$ and $14 \mathrm{~g} \mathrm{~kg}^{-1} \mathrm{DM}$ for fractions retained by $5.0,2.5,1.25,0.63,0.315,0.16$ and 0.08 $\mathrm{mm}$ sieves, respectively, and $360 \mathrm{~g} \mathrm{~kg}^{-1} \mathrm{DM}$ for the material $<0.08 \mathrm{~mm}$. It was assumed that the iNDF concentration of ingesta entering the rumen was the same as in the original silage and constant in different particle size fractions, and that there was no NDF in the DM not retained on the sieves. Because only a small proportion of ruminal digesta particles remained on the $2.5 \mathrm{~mm}$ sieve and a very small proportion of faecal particles remained on the $5.0 \mathrm{~mm}$ sieve, the data of these two sieves were combined for further calculations.

The NDF and iNDF pools of different particle size fractions of ruminal digesta and faeces were calculated as DM content of each particle size fraction multiplied by the respective NDF and iNDF concentrations. The pdNDF content was calculated as NDF minus iNDF content for each pool. The ruminal iNDF and pdNDF particle kinetic parameters were estimated by dividing the particulate DM into 6,3,2 or 1 fractions based on particle size (Figure 1). Changes in ruminal iNDF (and pdNDF) pools were described by the differential equations (Huhtanen et al., 2007):

$$
\begin{aligned}
& d \mathrm{iNDF}_{\mathrm{n}} d \mathrm{t}^{-1}=k_{i \mathrm{n}} \mathrm{iNDF}_{\mathrm{n}}-\left(k_{r \mathrm{n}}+k_{p \mathrm{n}}\right) \mathrm{iNDF}_{\mathrm{n}} \\
& \operatorname{diNDF}_{\mathrm{n}} d \mathrm{t}^{-1}=k_{\mathrm{in}} \mathrm{iNDF}_{\mathrm{n}}+k_{r(\mathrm{n}-1)} \mathrm{iNDF}_{(\mathrm{n}-1)}-\left(k_{r \mathrm{n}}+k_{p \mathrm{n}}\right) \mathrm{iNDF}_{\mathrm{n}} \\
& \operatorname{diNDF}_{\mathrm{n}} d \mathrm{t}^{-1}=k_{i \mathrm{n}} \mathrm{iNDF}_{\mathrm{n}}+k_{r(\mathrm{n}-1)} \mathrm{iNDF}_{(\mathrm{n}-1)}-k_{p \mathrm{n}} \mathrm{iNDF}_{\mathrm{n}}
\end{aligned}
$$

where: $k_{\mathrm{in}}, k_{\mathrm{pn}}$ and $k_{\mathrm{rm}}$ are the rate constants for intake, passage and breakdown of iNDF for each pool (n). The subscript (n - 1) refers to the larger pool in relation to the specific pool (n). Equation (1) was used for the first pool, equation (2) for the intermediate pools and equation (3) for the final pool. For the two-pool model, only equations (1) and (3) were used. As the pool sizes, $k_{i}$ and $k_{p}$ of iNDF were experimentally determined, $k_{r}$ and rate of digestion $\left(k_{\mathrm{d}}\right)$ of particles in the steady-state condition could be estimated by assuming similar $k_{r}$ for iNDF and pdNDF (Huhtanen et al., 2007). The ruminal mean 


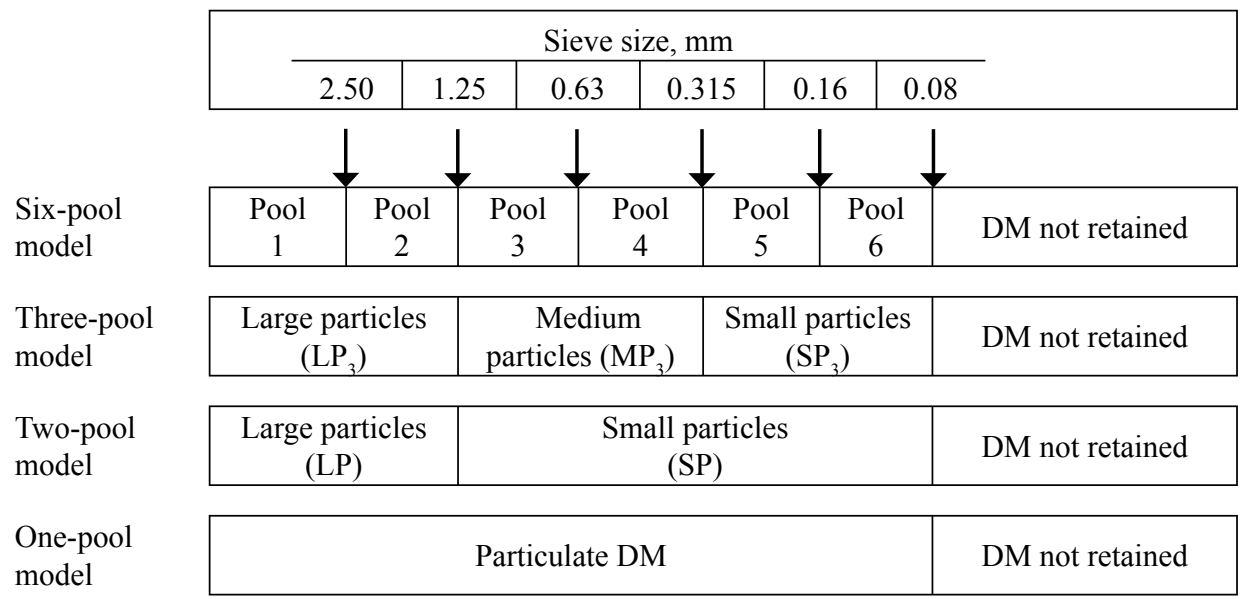

Figure 1. Division of dry matter (DM) into different fractions based on particle size

residence time (RMRT) of iNDF and mean turnover time of pdNDF in each particle size fraction was calculated as: [ruminal content of iNDF or pdNDF pool (g)] [quantity of iNDF or pdNDF entering into the pool $\left(\mathrm{g} \mathrm{h}^{-1}\right)$ via intake or breakdown from the other pools $]^{-1}$, based on the formula of Minson (1966). The median retaining aperture of ruminal digesta and faecal particles was calculated according to Fisher et al. (1988) using Proc NLIN of SAS (2003).

The following model was used to analyse the data of rumen evacuation and kinetic parameters using GLM procedure of SAS (2003):

$$
\mathrm{Y}_{i j k l}=\mu+C_{i}+P_{j}+T_{k}+S_{1}+e_{i j k l}
$$

where: $\mu$ is the overall mean, and $C_{i}, P_{j}, T_{k}$ and $S_{1}$ are the cow ( $i=1$ to 4$)$, period ( $j$ $=1$ to 4$)$, diet ( $k=1$ to 4$)$ and particle size $(1=1$ to 6$)$ effects, respectively, and $e_{i i k l}$ is the error term. Dietary treatments did not affect different parameters markedly and therefore only the mean values of the four treatments are reported and discussed. All the presented results are LS means and the differences were analysed using Duncan's multiple range test.

\section{RESULTS}

\section{Particle distribution, NDF and iNDF concentrations, and rumen pool sizes}

Based on the six-pool model, the greatest proportion of particles in the ruminal digesta remained on the $2.5 \mathrm{~mm}$ sieve and the lowest proportion on the $1.25 \mathrm{~mm}$ sieve (Table 1). The NDF concentration was similar in all fractions larger than 0.63 $\mathrm{mm}$, but for the smaller particles it decreased with decreasing particle size. 
Table 1. Dry matter (DM) distribution, and neutral detergent fibre (NDF) and indigestible NDF (iNDF) concentrations in different particle size fractions based on the six-pool model

\begin{tabular}{|c|c|c|c|c|c|c|c|}
\hline \multirow{2}{*}{ Item } & \multicolumn{6}{|c|}{ Particle size, $\mathrm{mm}$} & \multirow{2}{*}{$\mathrm{SEM}^{1}$} \\
\hline & $>2.5$ & $2.5-1.25$ & $1.25-0.63$ & $0.63-0.315$ & $0.315-0.16$ & $0.16-0.08$ & \\
\hline \multicolumn{8}{|c|}{ Ruminal digesta, $\mathrm{g} \mathrm{kg}^{-1}$ DM unless otherwise stated } \\
\hline DM distribution $^{2}$ & 295 & 50 & 135 & 216 & 158 & 145 & \\
\hline NDF & $912^{\mathrm{a}}$ & $909^{\mathrm{a}}$ & $916^{\mathrm{a}}$ & $897^{\mathrm{b}}$ & $844^{\mathrm{c}}$ & $682^{\mathrm{d}}$ & 2.8 \\
\hline iNDF & $520^{\mathrm{e}}$ & $631^{\mathrm{c}}$ & $700^{\mathrm{a}}$ & $654^{\mathrm{b}}$ & $555^{\mathrm{d}}$ & $348^{f}$ & 6.1 \\
\hline iNDF, $\mathrm{g} \mathrm{kg}^{-1} \mathrm{NDF}$ & $570^{\mathrm{e}}$ & $694^{\mathrm{c}}$ & $765^{\mathrm{a}}$ & $730^{\mathrm{b}}$ & $658^{\mathrm{d}}$ & $509^{f}$ & 7.6 \\
\hline \multicolumn{8}{|c|}{ Faeces, $\mathrm{g} \mathrm{kg}^{-1}$ DM unless otherwise stated } \\
\hline $\mathrm{DM}_{\text {distribution }}^{2}$ & 17 & 53 & 121 & 274 & 270 & 264 & \\
\hline NDF & $813^{\mathrm{c}}$ & $872^{\mathrm{ab}}$ & $911^{\mathrm{a}}$ & $902^{\mathrm{a}}$ & $844^{\mathrm{bc}}$ & $665^{\mathrm{d}}$ & 15.9 \\
\hline iNDF & $539^{d}$ & $681^{\mathrm{b}}$ & $755^{\mathrm{a}}$ & $754^{\mathrm{a}}$ & $629^{c}$ & $448^{\mathrm{e}}$ & 11.2 \\
\hline iNDF, $\mathrm{g} \mathrm{kg}^{-1} \mathrm{NDF}$ & $662^{\mathrm{b}}$ & $823^{\mathrm{a}}$ & $826^{\mathrm{a}}$ & $834^{\mathrm{a}}$ & $743^{\mathrm{ab}}$ & $673^{b}$ & 33.3 \\
\hline
\end{tabular}

${ }^{1} \mathrm{SEM}$ - standard error of the means; $\mathrm{n}=15 ;{ }^{2}$ as $\mathrm{g} \mathrm{kg}^{-1}$ particulate DM

$\mathrm{a}, \mathrm{b}, \mathrm{c}, \mathrm{d}, \mathrm{e}, \mathrm{f}$ means in a row with different superscripts differ statistically $(\mathrm{P}<0.05)$

The concentration of iNDF in NDF showed a quadratic trend being the highest in the $1.25-0.63 \mathrm{~mm}$ particles. The smallest ruminal particles $(0.16-0.08 \mathrm{~mm}) \mathrm{had}$ the lowest NDF and NDF concentrations.

Based on the six-pool model, the ruminal DM pool $>2.5 \mathrm{~mm}$ was the largest and the DM pool 2.5-1.25 mm was the smallest (Table 2). Also iNDF and pdNDF contents in the ruminal digesta showed the same trend. Both iNDF and pdNDF in 2.5-1.25 and 0.16-0.08 mm particles had the lowest RMRT and the highest ruminal mean turnover time, respectively. Based on the two-pool model, the RMRT of iNDF was 23.0 and $41.6 \mathrm{~h}$ and mean turnover time of pdNDF was 5.6 and $18.0 \mathrm{~h}$ in the non-escapable and escapable pools, respectively (data not presented).

In faeces, the smallest proportion of material remained on the $2.5 \mathrm{~mm}$ sieve and the majority of particles were below $0.63 \mathrm{~mm}$ (Table 1). The NDF concentration of faecal particles showed a similar trend as in ruminal digesta. However, the largest particles $(>2.5 \mathrm{~mm})$ had a lower NDF concentration than the other fractions larger than $0.315 \mathrm{~mm}$ ( $813 \mathrm{vs} 895 \mathrm{~g} \mathrm{~kg}^{-1}$ on average). The NDF concentration decreased in $0.315-0.16 \mathrm{~mm}$ particles $\left(844 \mathrm{~g} \mathrm{~kg}^{-1}\right)$ and further in the smallest particles $(0.16-0.08$ $\mathrm{mm}, 665 \mathrm{~g} \mathrm{~kg}^{-1}$ ). The iNDF concentration was the lowest in $>2.5$ and $0.16-0.08 \mathrm{~mm}$ particles. Ruminal and faecal DM not retained on the sieves comprised 358 and 473 $\mathrm{g} \mathrm{kg}^{-1}$ of total DM, respectively. For all particle size fractions the iNDF concentration in faecal particles was higher than in ruminal particles.

Based on the three-pool model, the ruminal particulate DM was fairly equally distributed among the three particle size fractions (Table 3 ). The majority of faecal particles was smaller than $0.315 \mathrm{~mm}$ and only a small proportion was larger than $1.25 \mathrm{~mm}$. Based on the two-pool model, the proportion of the small particles (SP, $1.25-0.08 \mathrm{~mm}$ ) in the rumen was 1.9 times greater than that of the large particles 
Table 2. Dry matter (DM), indigestible (iNDF) and potentially digestible (pdNDF) neutral detergent fibre contents of different particle size fractions and their ruminal mean residence time based on the six-pool model

\begin{tabular}{|c|c|c|c|c|c|c|c|}
\hline \multirow{2}{*}{ Item } & \multicolumn{6}{|c|}{ Particle size, $\mathrm{mm}$} & \multirow{2}{*}{ SEM $^{1}$} \\
\hline & $>2.5$ & $2.5-1.25$ & $1.25-0.63$ & $0.63-0.315$ & $0.315-0.16$ & $0.16-0.08$ & \\
\hline \multicolumn{8}{|c|}{ Ingested, $\mathrm{kg} \mathrm{d}^{-1}$} \\
\hline $\mathrm{DM}^{2}$ & $8.10^{\mathrm{a}}$ & $0.26^{\mathrm{c}}$ & $0.26^{\mathrm{c}}$ & $0.74^{\mathrm{b}}$ & $0.41^{\mathrm{c}}$ & $0.23^{\mathrm{c}}$ & 0.080 \\
\hline INDF & $1.48^{\mathrm{a}}$ & $0.05^{\mathrm{c}}$ & $0.05^{\mathrm{c}}$ & $0.14^{\mathrm{b}}$ & $0.08^{\mathrm{c}}$ & $0.04^{\mathrm{c}}$ & 0.020 \\
\hline pdNDF & $4.31^{\mathrm{a}}$ & $0.13^{\mathrm{c}}$ & $0.13^{\mathrm{c}}$ & $0.38^{\mathrm{b}}$ & $0.22^{\mathrm{c}}$ & $0.12^{\mathrm{c}}$ & 0.047 \\
\hline \multicolumn{8}{|c|}{ Ruminal digesta, $\mathrm{kg}$} \\
\hline $\mathrm{DM}$ & $2.34^{\mathrm{a}}$ & $0.40^{\mathrm{e}}$ & $1.06^{\mathrm{d}}$ & $1.70^{\mathrm{b}}$ & $1.24^{\mathrm{c}}$ & $1.14^{\mathrm{cd}}$ & 0.049 \\
\hline INDF & $1.21^{\mathrm{a}}$ & $0.26^{\mathrm{e}}$ & $0.74^{\mathrm{c}}$ & $1.11^{\mathrm{b}}$ & $0.69^{\mathrm{c}}$ & $0.40^{\mathrm{d}}$ & 0.028 \\
\hline $\mathrm{pdNDF}$ & $0.92^{\mathrm{a}}$ & $0.11^{\mathrm{d}}$ & $0.23^{\mathrm{c}}$ & $0.41^{\mathrm{b}}$ & $0.36^{\mathrm{b}}$ & $0.38^{\mathrm{b}}$ & 0.022 \\
\hline \multicolumn{8}{|c|}{ Faeces, $\mathrm{kg} \mathrm{d}^{-1}$} \\
\hline $\mathrm{DM}$ & $0.05^{\mathrm{d}}$ & $0.16^{\mathrm{c}}$ & $0.36^{\mathrm{b}}$ & $0.80^{\mathrm{a}}$ & $0.80^{\mathrm{a}}$ & $0.76^{\mathrm{a}}$ & 0.027 \\
\hline INDF & $0.03^{\mathrm{f}}$ & $0.11^{\mathrm{e}}$ & $0.27^{\mathrm{d}}$ & $0.60^{\mathrm{a}}$ & $0.49^{\mathrm{b}}$ & $0.34^{\mathrm{c}}$ & 0.016 \\
\hline pdNDF & $0.01^{\mathrm{d}}$ & $0.04^{\mathrm{cd}}$ & $0.06^{\mathrm{c}}$ & $0.12^{\mathrm{b}}$ & $0.18^{\mathrm{a}}$ & $0.16^{\mathrm{a}}$ & 0.010 \\
\hline \multicolumn{8}{|c|}{ Ruminal mean residence time, $h$} \\
\hline $\mathrm{INDF}^{3}$ & $19.7^{\mathrm{b}}$ & $4.2^{\mathrm{d}}$ & $12.5^{\mathrm{c}}$ & $20.4^{\mathrm{b}}$ & $21.1^{\mathrm{b}}$ & $29.4^{\mathrm{a}}$ & 1.09 \\
\hline $\mathrm{pdNDF}^{4}$ & $5.2^{\mathrm{e}}$ & $2.2^{\mathrm{f}}$ & $7.4^{\mathrm{d}}$ & $13.2^{\mathrm{c}}$ & $18.1^{\mathrm{b}}$ & $33.3^{\mathrm{a}}$ & 0.58 \\
\hline
\end{tabular}

${ }^{1}$ SEM - standard error of the means; $n=15$

${ }^{2}$ estimated based on the particle size distribution data adopted from Rinne et al. (2002)

${ }^{3}$ calculated as $\left(k_{\mathrm{p}}+k_{\mathrm{r}}\right)^{-1}$ for each particle size fraction; $k_{\mathrm{p}}$ and $k_{\mathrm{r}}$ are from iNDF kinetics (Table 5)

${ }^{4}$ calculated as $\left(k_{\mathrm{p}}+k_{\mathrm{r}}+k_{\mathrm{d}}\right)^{-1}$ for each particle size fraction; $k_{\mathrm{r}}$ is the same as $k_{\mathrm{r}}$ of iNDF and $k_{\mathrm{p}}$ and $k_{\mathrm{d}}$ are from pdNDF kinetics (Table 5)

$\mathrm{a}, \mathrm{b}, \mathrm{c}, \mathrm{d}, \mathrm{e}, \mathrm{f}$ means in a row with different superscripts differ statistically $(\mathrm{P}<0.05)$

Table 3. Dry matter (DM) distribution, and neutral detergent fibre (NDF) and indigestible NDF (iNDF) concentrations in different particle size fractions based on the three-pool model

\begin{tabular}{lcccc}
\hline \multirow{2}{*}{ Item } & \multicolumn{3}{c}{ Particle size, $\mathrm{mm}$} & \multirow{2}{*}{ SEM $^{1}$} \\
\cline { 2 - 3 } Ruminal digesta, $\mathrm{g} \mathrm{kg}^{-1}$ & $>1.25$ & $1.25-0.315$ & $0.315-0.08$ & \\
DM distribution & & & \\
NDF & 346 & 351 & 303 & \\
iNDF & $912^{\mathrm{a}}$ & $904^{\mathrm{b}}$ & $767^{\mathrm{c}}$ & 2.6 \\
iNDF, $\mathrm{g} \mathrm{kg}^{-1} \mathrm{NDF}$ & $536^{\mathrm{b}}$ & $672^{\mathrm{a}}$ & $450^{\mathrm{c}}$ & 5.3 \\
Faeces, $\mathrm{g} \mathrm{kg}^{-1}$ DM unless otherwise stated & $588^{\mathrm{b}}$ & $744^{\mathrm{a}}$ & $587^{\mathrm{b}}$ & 6.5 \\
DM distribution & & & \\
NDF & 71 & 395 & 534 & \\
iNDF & $856^{\mathrm{a}}$ & $906^{\mathrm{a}}$ & $757^{\mathrm{b}}$ & 19.2 \\
iNDF, g kg-1 NDF & $646^{\mathrm{b}}$ & $755^{\mathrm{a}}$ & $537^{\mathrm{c}}$ & 9.3 \\
\hline
\end{tabular}

${ }^{1}$ SEM - standard error of the means; $n=15$

${ }^{2}$ as $\mathrm{g} \mathrm{kg}^{-1}$ particulate DM

${ }^{a, b, c}$ means in a row with different superscripts differ statistically $(\mathrm{P}<0.05)$ 
$(\mathrm{LP},>1.25 \mathrm{~mm})$ (Table 4). The median retaining aperture was 1.05 (standard deviation 0.228$), 0.71(0.109)$ and $0.30(0.015) \mathrm{mm}$ in ruminal digesta at post- and pre-feeding and in faeces, respectively.

Table 4. Dry matter (DM) distribution, and neutral detergent fibre (NDF) and indigestible NDF (iNDF) concentrations in different particle size fractions based on the two-pool model

\begin{tabular}{|c|c|c|c|}
\hline \multirow{2}{*}{ Item } & \multicolumn{2}{|c|}{ Particle size, $\mathrm{mm}$} & \multirow{2}{*}{ SEM $^{1}$} \\
\hline & $>1.25$ & $1.25-0.08$ & \\
\hline \multicolumn{4}{|c|}{ Ruminal digesta, $g \mathrm{~kg}^{-1}$ DM unless otherwise stated } \\
\hline DM distribution $^{2}$ & 346 & 654 & \\
\hline $\mathrm{NDF}$ & $912^{\mathrm{a}}$ & $840^{\mathrm{b}}$ & 1.5 \\
\hline iNDF & $537^{\mathrm{b}}$ & $564^{\mathrm{a}}$ & 3.1 \\
\hline iNDF, $\mathrm{g} \mathrm{kg}^{-1} \mathrm{NDF}$ & $588^{\mathrm{b}}$ & $671^{\mathrm{a}}$ & 3.4 \\
\hline \multicolumn{4}{|c|}{ Faeces, $\mathrm{kg}^{-1}$ DM unless otherwise stated } \\
\hline DM distribution $^{2}$ & 71 & 929 & \\
\hline $\mathrm{NDF}$ & 858 & 822 & 23.5 \\
\hline iNDF & 647 & 626 & 10.2 \\
\hline iNDF, $\mathrm{g} \mathrm{kg}^{-1} \mathrm{NDF}$ & 784 & 756 & 49.5 \\
\hline
\end{tabular}

${ }^{1}$ SEM - standard error of the means; $\mathrm{n}=15$

${ }^{2}$ as $\mathrm{g} \mathrm{kg}^{-1}$ particulate DM

a,b means in a row with different superscripts differ statistically $(\mathrm{P}<0.05)$

\section{Rumen digesta kinetics}

Based on the six-pool model, most of the ingested iNDF entered the large particle pool $\left(>2.5 \mathrm{~mm}\right.$ ) (Table 5). The $k_{p}$ of iNDF of the particles $>2.5 \mathrm{~mm}$ $\left(\mathrm{iNDF}_{2.5}\right.$ ) was clearly slower than that of the other particle size fractions. The $k_{p}$ of iNDF of the $2.5-1.25$ and $1.25-0.63 \mathrm{~mm}$ particles was similar and it increased linearly with decreasing particle size. The $k_{r}$ of $2.5-1.25 \mathrm{~mm}$ particles was clearly faster $(0.237$ $\mathrm{h}^{-1}$ ) than that of any other pool. The contribution of particle breakdown in clearance of iNDF from rumen pools, calculated as $k_{\mathrm{r}}\left(k_{\mathrm{r}}+k_{\mathrm{p}}\right)^{-1}$ of iNDF, decreased linearly with decreasing size of particles. The $k_{p}$ of pdNDF in particles $>2.5 \mathrm{~mm}\left(\mathrm{pdNDF}_{2.5}\right)$ was very slow $\left(0.001 \mathrm{~h}^{-1}\right)$ and it was the fastest in the $0.315-0.16 \mathrm{~mm}\left(\mathrm{pdNDF}_{0.16}\right)$ and 0.16-0.08 mm ( pdNDF $_{0.08}$ ) particles. The pdNDF in the $2.5-1.25 \mathrm{~mm}$ particles had the fastest $k_{\mathrm{d}}$ and generally $k_{\mathrm{d}}$ decreased with decreasing particle size. The contribution of digestion in clearance of pdNDF from rumen pools calculated as $k_{\mathrm{d}}\left(k_{\mathrm{d}}+k_{\mathrm{p}}+k_{\mathrm{r}}\right)^{-1}$ was the highest for $\mathrm{pdNDF}_{2.5}$ and the lowest for $\mathrm{pdNDF}_{0.16}(0.74$ and 0.30 , respectively). The efficiency of selective retention [calculated as ( $k_{p}$ of iNDF) $\left(k_{p} \text { of pdNDF) }\right)^{-1}$, Huhtanen et al., 2007] was the highest in the $0.63-0.315$ and $0.16-0.08 \mathrm{~mm}$ pools.

Based on the three-pool model, most of the ingested iNDF entered the large pool $\left(\mathrm{LP}_{3},>1.25 \mathrm{~mm}\right.$ ) (Table 6). The $k_{p}$ of iNDF increased linearly with decreasing particle size. The $k_{r}$ of $\mathrm{LP}_{3}$ was greater than that of the medium particles $\left(\mathrm{MP}_{3}\right.$, $1.25-0.315 \mathrm{~mm})$. The contribution of breakdown in clearance of iNDF from ru- 
Table 5. Rates of intake $\left(k_{i}\right)$, passage $\left(k_{p}\right)$, particle breakdown $\left(k_{r}\right)$ and digestion $\left(k_{\mathrm{d}}\right)$, and the efficiency of selective retention estimated based on the six-pool model

\begin{tabular}{|c|c|c|c|c|c|c|c|}
\hline \multirow{2}{*}{ Item } & \multicolumn{6}{|c|}{ Particle size, $\mathrm{mm}$} & \multirow{2}{*}{ SEM $^{1}$} \\
\hline & $>2.5$ & $2.5-1.25$ & $1.25-0.63$ & $0.63-0.315$ & $0.315-0.16$ & $0.16-0.08$ & \\
\hline \multicolumn{8}{|c|}{ Indigestible neutral detergent fibre (iNDF) } \\
\hline$k_{\mathrm{i}}, \mathrm{h}^{-1}$ & $0.053^{\mathrm{a}}$ & $0.008^{\mathrm{b}}$ & $0.003^{\mathrm{c}}$ & $0.005^{\mathrm{bc}}$ & $0.005^{\mathrm{c}}$ & $0.005^{\mathrm{c}}$ & 0.0010 \\
\hline$k_{\mathrm{p}}, \mathrm{h}^{-1}$ & $0.001^{\mathrm{e}}$ & $0.017^{\mathrm{d}}$ & $0.015^{\mathrm{d}}$ & $0.023^{\mathrm{c}}$ & $0.030^{\mathrm{b}}$ & $0.037^{\mathrm{a}}$ & 0.0013 \\
\hline$k_{\mathrm{r}}^{\mathrm{p}}, \mathrm{h}^{-1}$ & $0.051^{\mathrm{c}}$ & $0.239^{\mathrm{a}}$ & $0.067^{\mathrm{b}}$ & $0.027^{\mathrm{d}}$ & $0.018^{\mathrm{d}}$ & - & 0.0046 \\
\hline$k_{\mathrm{r}}\left(k_{\mathrm{r}}+k_{\mathrm{p}}\right)^{-1}$ & $0.98^{\mathrm{a}}$ & $0.93^{b}$ & $0.82^{\mathrm{c}}$ & $0.54^{\mathrm{d}}$ & $0.38^{\mathrm{e}}$ & - & 0.011 \\
\hline \multicolumn{8}{|c|}{ Potentially digestible neutral detergent fibre $(p d N D F)^{2}$} \\
\hline$k_{\mathrm{i}}, \mathrm{h}^{-1}$ & $0.204^{\mathrm{a}}$ & $0.052^{\mathrm{b}}$ & $0.025^{\mathrm{c}}$ & $0.040^{\mathrm{b}}$ & $0.026^{\mathrm{c}}$ & $0.014^{\mathrm{c}}$ & 0.0043 \\
\hline$k_{\mathrm{p}}, \mathrm{h}^{-1}$ & $0.001^{\mathrm{c}}$ & $0.013^{\mathrm{b}}$ & $0.010^{\mathrm{b}}$ & $0.012^{\mathrm{b}}$ & $0.020^{\mathrm{a}}$ & $0.018^{\mathrm{a}}$ & 0.0013 \\
\hline$k_{\mathrm{d}}^{\mathrm{p}}, \mathrm{h}^{-1}$ & $0.151^{\mathrm{b}}$ & $0.225^{\mathrm{a}}$ & $0.062^{\mathrm{c}}$ & $0.039^{\mathrm{d}}$ & $0.018^{\mathrm{e}}$ & $0.012^{\mathrm{e}}$ & 0.0058 \\
\hline$k_{\mathrm{d}}\left(k_{\mathrm{r}}+k_{\mathrm{p}}+k_{\mathrm{d}}\right)^{-1}$ & $0.74^{\mathrm{a}}$ & $0.47^{\mathrm{b}}$ & $0.44^{\mathrm{b}}$ & $0.48^{\mathrm{b}}$ & $0.30^{\mathrm{c}}$ & $0.40^{\mathrm{b}}$ & 0.022 \\
\hline \multicolumn{8}{|c|}{ Efficiency of selective retention } \\
\hline$k_{\mathrm{p} \mathrm{iNDF}}\left(k_{\mathrm{p} \mathrm{pdNDF}}\right)^{-1}$ & $1.69^{\mathrm{bc}}$ & $1.47^{\mathrm{c}}$ & $1.53^{\mathrm{c}}$ & $2.00^{\mathrm{ab}}$ & $1.64^{\mathrm{bc}}$ & $2.30^{\mathrm{a}}$ & 0.150 \\
\hline
\end{tabular}

${ }^{1} \mathrm{SEM}$ - standard error of the means; $\mathrm{n}=15$

${ }^{2}$ the $k_{\mathrm{r}}$ of pdNDF is assumed to be equal to that of iNDF

$\mathrm{a}, \mathrm{b}, \mathrm{c}, \mathrm{d}, \mathrm{r}$ means in a row with different superscripts differ statistically $(\mathrm{P}<0.05)$

minal pools was higher for $\mathrm{LP}_{3}$ than for $\mathrm{MP}_{3}$. The $k_{p}$ of pdNDF increased and $k_{d}$ decreased linearly with decreasing particle size. The contribution of digestion in the clearance of pdNDF from ruminal pools was lower for the small particles $\left(\mathrm{SP}_{3}\right.$, $0.315-0.08 \mathrm{~mm}$ ) than for the other pools. The efficiency of selective retention for $\mathrm{LP}_{3}$ was higher than for the other pools, but the difference was not statistically significant.

Table 6. Rates of intake $\left(k_{i}\right)$, passage $\left(k_{p}\right)$, particle breakdown $\left(k_{r}\right)$ and digestion $\left(k_{\mathrm{d}}\right)$, and the efficiency of selective retention estimated based on the three-pool model

\begin{tabular}{|c|c|c|c|c|}
\hline \multirow{2}{*}{ Item } & \multicolumn{3}{|c|}{ Particle size, $\mathrm{mm}$} & \multirow{2}{*}{ SEM $^{1}$} \\
\hline & $>1.25$ & $1.25-0.315$ & $0.315-0.08$ & \\
\hline \multicolumn{5}{|c|}{ Indigestible neutral detergent fibre (iNDF) } \\
\hline$k_{\mathrm{i}}, \mathrm{h}^{-1}$ & $0.045^{\mathrm{a}}$ & $0.004^{\mathrm{b}}$ & $0.005^{\mathrm{b}}$ & 0.0011 \\
\hline$k_{\mathrm{p}}, \mathrm{h}^{-1}$ & $0.004^{\mathrm{c}}$ & $0.020^{\mathrm{b}}$ & $0.032^{\mathrm{a}}$ & 0.0007 \\
\hline$k_{\mathrm{r}}, \mathrm{h}^{-1}$ & $0.041^{\mathrm{a}}$ & $0.016^{\mathrm{b}}$ & - & 0.0012 \\
\hline$k_{\mathrm{r}}\left(k_{\mathrm{r}}+k_{\mathrm{p}}\right)^{-1}$ & $0.91^{\mathrm{a}}$ & $0.45^{\mathrm{b}}$ & - & 0.008 \\
\hline \multicolumn{5}{|c|}{ Potentially digestible neutral detergent fibre $(p d N D F)^{2}$} \\
\hline$k_{\mathrm{i}}, \mathrm{h}^{-1}$ & $0.019^{\mathrm{a}}$ & $0.035^{\mathrm{b}}$ & $0.020^{\mathrm{c}}$ & 0.0050 \\
\hline$k_{\mathrm{p}}, \mathrm{h}^{-1}$ & $0.002^{\mathrm{c}}$ & $0.011^{\mathrm{b}}$ & $0.019^{\mathrm{a}}$ & 0.0011 \\
\hline$k_{\mathrm{d}}, \mathrm{h}^{-1}$ & $0.144^{\mathrm{a}}$ & $0.072^{\mathrm{b}}$ & $0.014^{\mathrm{c}}$ & 0.0047 \\
\hline$k_{\mathrm{d}}\left(k_{\mathrm{r}}+k_{\mathrm{p}}+k_{\mathrm{d}}\right)^{-1}$ & $0.77^{\mathrm{a}}$ & $0.72^{\mathrm{a}}$ & $0.42^{\mathrm{b}}$ & 0.026 \\
\hline \multicolumn{5}{|c|}{ Efficiency of selective retention } \\
\hline$k_{\mathrm{p} \mathrm{iNDF}}\left(k_{\mathrm{p} \mathrm{pdNDF}}\right)^{-1}$ & 2.01 & 1.80 & 1.89 & 0.130 \\
\hline
\end{tabular}

${ }^{1} \mathrm{SEM}$ - standard error of the means; $\mathrm{n}=15$

${ }^{2}$ the $k_{\mathrm{r}}$ of pdNDF is assumed to be equal to that of iNDF

a, b, c Means in a row with different superscripts differ statistically $(\mathrm{P}<0.05)$ 
Table 7. Rates of intake $\left(k_{i}\right)$, passage $\left(k_{p}\right)$, particle breakdown $\left(k_{r}\right)$ and digestion $\left(k_{\mathrm{d}}\right)$, and the efficiency of selective retention estimated based on the two-pool model

\begin{tabular}{lccc}
\hline \multirow{2}{*}{ Item } & \multicolumn{2}{c}{ Particle size, $\mathrm{mm}$} & \multirow{2}{*}{ SEM $^{1}$} \\
\cline { 2 - 3 } & \multicolumn{1}{c}{1.25} & $1.25-0.08$ & \\
\cline { 2 - 3 } Indigestible neutral detergent fibre $(i N D F), \mathrm{h}^{-1}$ & $0.045^{\mathrm{a}}$ & $0.004^{\mathrm{b}}$ & 0.0013 \\
$k_{\mathrm{p}}, \mathrm{h}^{-1}$ & $0.004^{\mathrm{b}}$ & $0.024^{\mathrm{a}}$ & 0.0005 \\
$k_{\mathrm{r}}, \mathrm{h}^{-1}$ & 0.041 & - & - \\
$k_{\mathrm{r}}\left(k_{\mathrm{r}}+k_{\mathrm{p}}\right)^{-1}$ & 0.91 & - & - \\
Potentially digestible neutral detergent fibre $(p d N D F)^{2}$ & & \\
$k_{\mathrm{i}}, \mathrm{h}^{-1}$ & $0.187^{\mathrm{a}}$ & $0.027^{\mathrm{b}}$ & 0.0059 \\
$k_{\mathrm{p}}, \mathrm{h}^{-1}$ & $0.002^{\mathrm{b}}$ & $0.016^{\mathrm{a}}$ & 0.0007 \\
$k_{\mathrm{d}}, \mathrm{h}^{-1}$ & $0.143^{\mathrm{a}}$ & $0.040^{\mathrm{b}}$ & 0.0050 \\
$k_{\mathrm{d}}\left(k_{\mathrm{r}}+k_{\mathrm{p}}+k_{\mathrm{d}}\right)^{-1}$ & $0.77^{\mathrm{a}}$ & $0.72^{\mathrm{b}}$ & 0.011 \\
Efficiency of selective retention & & & \\
$k_{\mathrm{p} \text { iNDF }}\left(k_{\mathrm{p} \mathrm{pdNDF}}\right)^{-1}$ & 2.02 & 1.69 & 0.131 \\
\hline
\end{tabular}

${ }^{1}$ SEM - standard error of the means; $n=15$

${ }^{2}$ the $k_{\mathrm{r}}$ of pdNDF is assumed to be equal to that of iNDF

${ }^{\mathrm{a}, \mathrm{b}}$ means in a row with different superscripts differ statistically $(\mathrm{P}<0.05)$

Based on the two-pool model, $k_{p}$ of iNDF and pdNDF for SP were higher than those of LP (Table 7). The $k_{r}$ of LP was $0.041 \mathrm{~h}^{-1}$, and most of iNDF clearance from LP took place through breakdown of particles $(0.91)$. The $k_{\mathrm{d}}$ and the contribution of digestion in clearance of pdNDF were higher in LP compared to SP. The efficiency of selective retention was numerically, though not significantly, higher in LP than in SP.

Considering total ruminal digesta as one pool, $k_{p}$ of iNDF was $0.017 \mathrm{~h}^{-1}$ and $k_{p}$ and $k_{d}$ of pdNDF were 0.010 and $0.083 \mathrm{~h}^{-1}$, respectively. Rumen iNDF and pdNDF contents were 4.35 and $2.40 \mathrm{~kg}$, respectively, and 0.89 of total pdNDF disappearance from rumen took place through digestion. The efficiency of selective retention was 1.87 .

\section{DISCUSSION}

\section{Particle distribution, NDF and iNDF concentrations and rumen pool sizes}

Ruminal contents were evacuated $1 \mathrm{~h}$ before and $2.5 \mathrm{~h}$ after feeding. Huhtanen et al. (2007) concluded that these evacuation times in cattle fed twice daily represent the minimum and maximum rumen contents and are likely to result in accurate estimates of the mean pool size. Particle size distribution of ingested material was not measured, but in the studies of Bruining et al. (1998) and Huhtanen et 
al. (2007) it was similar to the data of Rinne et al. (2002), which was used in the present study. Possible errors, especially in the largest particle fraction would not markedly influence the results.

In the present study, DM $<0.08 \mathrm{~mm}$ formed $358 \mathrm{~g} \mathrm{~kg}^{-1}$ of ruminal digesta, which is within the range reported by Bruining et al. (1998) and Rinne et al. (2002) in dairy cows but slightly higher than that measured by Huhtanen et al. (2007) in growing cattle. This variation can be related to forage species, growth stage, diet composition and sieving techniques. Because the large proportion of $\mathrm{DM}$ is generally not retained on the sieves, it is crucial to note whether the results are presented on particulate or total DM basis.

The highest proportion of the ruminal digesta particles remained on the $2.5 \mathrm{~mm}$ sieve and the lowest remained on the $1.25 \mathrm{~mm}$ sieve consistently with Ahvenjärvi et al. (2001). Ahvenjärvi et al. (2001) speculated that during rumination the particles were comminuted below $1.25 \mathrm{~mm}$, and particles larger than $2.5 \mathrm{~mm}$ had not yet been subjected to rumination. Also Ulyatt et al. (1986) indicated that in cattle proportionally from 0.56 to 0.92 of the particulate DM is reduced in size to smaller than $1.0 \mathrm{~mm}$ during rumination. Accurate estimation of $k_{\mathrm{r}}$ would need a comparison of particle size distribution in the regurgitated and the ruminated boluses to measure the contribution of rumination to the magnitude of particle breakdown.

Based on the three-pool model, the proportion of $\mathrm{LP}_{3}$ in ruminal digesta was lower and those of $\mathrm{MP}_{3}$ and $\mathrm{SP}_{3}$ were higher than those reported by Rinne et al. (2002), respectively.

Based on the two-pool model, the proportion of LP in ruminal digesta was smaller than that of SP. This is in contrast with Bruining et al. (1998) using grass, maize and lucerne silages and Huhtanen et al. (2007) using timothy hay. However, the present results are consistent with the data reported by Bosch et al. (1992) and Bosch and Bruining (1995), who observed that the small particle fraction was larger than the large particle fraction with grass silage based diets.

It should be noted that sieving techniques varied between the studies. In the current experiment, more than $750 \mathrm{~g} \mathrm{~kg}^{-1}$ of ruminal DM content was $<1.25 \mathrm{~mm}$. Shaver et al. (1988) and Prigge et al. (1993) indicated that more than half of ruminal DM was smaller than $1.18 \mathrm{~mm}$. These findings support the concept that other factors beside particle size affect the passage of forage particles from the rumen. One of those factors is the functional specific gravity of particles (Sutherland, 1988). Poppi et al. (2001) discussed that a large proportion of particles smaller than the threshold for passage are entrapped in rumen raft and are not eligible to immediate passage.

The proportion of faecal DM that remained on the $2.5 \mathrm{~mm}$ sieve was only 0.009 but this value was 0.037 for the particles $>1.25 \mathrm{~mm}$ (data not presented). Poppi et al. (1980) suggested a critical particle size theory and defined the critical particle size as the sieve size that retains proportionally 0.05 of faecal DM. According to that concept, the critical particle size in this experiment would be slightly below 
$1.25 \mathrm{~mm}$. Bruining et al. (1998) reported a considerable proportion (110-140 g $\left.\mathrm{kg}^{-1}\right)$ of large particles $(>1.25 \mathrm{~mm})$ in faecal DM. The findings of this study are in contrast with those of Shaver et al. (1988) and Oshita et al. (2004), who indicated that the critical particle size in dairy cows or steers was greater than reported previously for sheep and cattle (Poppi et al., 1980). Oshita et al. (2004) found that the proportion of faecal DM remained on the $4 \mathrm{~mm}$ screen was much higher for maize silage than for lucerne hay, lucerne silage and orchard grass hay.

In this experiment, the proportion of faecal DM below $0.08 \mathrm{~mm}$ was $473 \mathrm{~g}$ $\mathrm{kg}^{-1}$ DM. Rinne et al. (2002) reported values between 529 to $321 \mathrm{~g} \mathrm{~kg}^{-1}$ which decreased with advancing maturity of grass ensiled. The median retaining aperture values in the present experiment were lower in ruminal digesta but similar in faeces compared to those of Rinne et al. (2002). This difference may at least partly be related to the differences in the cell wall structure between grasses and legumes.

The NDF and iNDF concentrations in ruminal particles showed a curvilinear trend with decreasing particle size comparable to the observations of Huhtanen et al. (1993) and Ahvenjärvi et al. (2001). Lower NDF concentration in small particles can be attributed to the greater attachment of bacteria to small particles compared to large particles (Legay-Carmier and Bauchart, 1989), which is supported by higher particle-associated enzyme activities in the smallest particles (Huhtanen et al., 1993). The iNDF concentration in NDF in both ruminal and faecal particles showed a quadratic trend being highest in medium size particles. It is likely that the changes from large particle fraction to medium particle fraction reflect mainly the digestion and breakdown of stems while the small particle fraction originates mainly from leaves, which are from different morphological origin. Increasing iNDF concentration in NDF with decreasing particle size indicates that the smaller particles had been subjected to digestion for a longer period of time than the larger particles. The iNDF concentration in NDF in faecal particles was higher than that in the respective particle size fractions of ruminal digesta in agreement with Ahvenjärvi et al. (2001) and Huhtanen et al. (2007). This can be attributed to the selective retention of feed particles in the rumen and post-ruminal fibre digestion.

According to the two-pool model, the NDF concentration was higher in LP than in SP but the iNDF concentration was higher in SP in agreement with the observations of Ahvenjärvi et al. (2001). In the present study the NDF concentration was $865 \mathrm{~g} \mathrm{~kg}^{-1} \mathrm{DM}$ and the iNDF concentration was $642 \mathrm{~g} \mathrm{~kg}^{-1} \mathrm{NDF}$ in total ruminal particulate matter. Bruining et al. (1998) observed that the rumen indigestible DM concentration for grass, maize and lucerne silages was significantly different (on average 540, 370 and $840 \mathrm{~g} \mathrm{~kg}^{-1}$ of ruminal particulate DM, respectively).

The total pdNDF and iNDF ruminal pools were 2.40 and $4.35 \mathrm{~kg}$, respectively. The iNDF pool in this experiment was proportionally much greater than reported by Rinne et al. (2002), Ahvenjärvi et al. (2006) and Huhtanen et al. (2007) using diets based on grass silage. This discrepancy may be due to the structural dif- 
ferences between legumes and grasses (Tamminga, 1993; Bruining et al., 1998; Kuoppala et al., 2005).

\section{Ruminal mean residence time}

Based on the six-pool model, RMRT of iNDF and mean turnover time of pdNDF in different pools increased with decreasing particle size but the largest particle size fraction was an exception. The largest particles can not escape from the rumen directly and they have to be reduced in size mainly through rumination. Therefore the higher mean residence time of these particles may indicate the important contribution of rumination in their clearance from the rumen. Markedly longer RMRT of $\mathrm{iNDF}_{2.5}$ compared to the mean turnover time of $\mathrm{pdNDF}_{2.5}$ is due to the fast $k_{\mathrm{d}}$ of $\mathrm{pdNDF}_{2.5}$. Increasing RMRT with decreasing particle size except for $\mathrm{iNDF}_{2.5}$ in spite of increased $k_{p}$ can be explained by reducing contribution of particle breakdown to clearance of iNDF pools. Lund et al. (2007) emphasized the important impact of $k_{\mathrm{d}}$ and distribution of mean retention time between escapable and non-escapable ruminal pools on the mean turnover time of pdNDF. They used marker derived kinetic parameters and rumen evacuation technique based on the two compartment model. However, in the current experiment, the $k_{\mathrm{d}}$ is taken into account in estimating mean turnover time of pdNDF using rumen evacuation technique, wet sieving and iNDF determination.

The RMRT of iNDF calculated by the steady-state method was longer than the value based on $\mathrm{Yb}$ kinetics from the same experiment $(57.3$ and $32.1 \mathrm{~h}$, respectively; Khalili and Huhtanen, 2002). It has been reported that Yb-labelled particles underestimate the RMRT (Huhtanen and Kukkonen, 1995; Lund, 2002) and it may be related to migration of $\mathrm{Yb}$ to rumen fluid (Beauchemin and Buchanan-Smith, 1989; Combs et al., 1992) or preferential bounding to small rather than large particles (Siddons et al., 1985).

\section{Rumen digesta kinetics}

The $k_{p}$ increased linearly with decreasing particle size which is generally observed in other studies (Poppi et al., 1980; Rinne et al., 2002; Huhtanen et al., 2007). The $k_{p}$ of $\mathrm{iNDF}_{2.5}$ was markedly lower than those of the other pools indicating that these particles are not eligible to escape from the rumen. The $k_{p}$ of pdNDF was lower than that of iNDF for all pools. Tamminga et al. (1989) found a higher fractional $k_{p}$ for iNDF than for pdNDF and Huhtanen et al. (2007) reported that the $k_{p}$ of iNDF was higher than that of pdNDF irrespective of particle size. Harvatine et al. (2002) pointed out that both iNDF and pdNDF are within the same particles and thus have the same $k_{\mathrm{p}}$. However, the distribution of particles with different concentrations of pdNDF relative to iNDF in rumen outflow causes the differences in $k_{\mathrm{p}}$ 
of pdNDF and iNDF. The $k_{p}$ of $\mathrm{pdNDF}_{0.16}$ and $\mathrm{pdNDF}_{0.08}$ were faster than those of the other particle size fractions and proportionally 0.61 of pdNDF outflow from the rumen occurred in these particle size fractions.

Based on the three-pool model, $k_{\mathrm{r}}$ of $\mathrm{LP}_{3}\left(0.041 \mathrm{~h}^{-1}\right)$ was similar to the values of Bruining et al. (1998) and Huhtanen et al. (2007). These studies using indigestible fractions in steady-state rumen models indicate that forage particle breakdown is a relatively slow process. The proportion of iNDF clearance through breakdown shows that in particles $>0.63 \mathrm{~mm}$ breakdown was predominant, in $0.63-0.315 \mathrm{~mm}$ particles, both breakdown and passage had an equal contribution, and in particles $<0.315 \mathrm{~mm}$ passage was predominant. These findings support the concept of the rumen raft model (Poppi et al., 2001).

The efficiency of selective retention did not show any special trend in different ruminal pools. Huhtanen et al. (2007) also observed that the efficiency of selective retention was not related to particle size. The mechanisms such as functional specific gravity (Sutherland, 1988) and entrapment of small particles in the ruminal fibrous mat (Poppi et al., 2001) involved in regulating the passage of feed particles from the rumen may contribute to it.

Based on the two-pool model, $k_{p}$ of SP was slower than $k_{r}$ of LP. This observation is in contrast with Huhtanen et al. (2007) who suggested that the rate of large particle breakdown rather than the passage rate of small particles was the rate limiting step in rumen clearance. This discrepancy may again be related to the differences between grasses and legumes. In the present study $k_{r}$ was on average 0.041, which is consistent with the values reported by Bruining et al. (1998) and Huhtanen et al. (2007).

The faster $k_{\mathrm{d}}$ of LP compared to SP based on the two-pool model is in agreement with the results of Bruining et al. (1998) and Huhtanen et al. (2007). The smaller $k_{\mathrm{d}}$ of SP compared to LP may be related to depletion of the most rapidly digestible cell wall material from the particles with decreasing particle size and increasing rumen residence time (Huhtanen et al., 2007). The ruminal $k_{\mathrm{d}}$ of total pdNDF in this experiment $\left(0.083 \mathrm{~h}^{-1}\right)$ was higher than the value of $0.067 \mathrm{~h}^{-1}$ for timothy hay reported by Huhtanen et al. (2007). Bruining et al. (1998) observed that $k_{\mathrm{d}}$ was markedly faster in lucerne silage compared to grass and maize silages supported by the well-documented differences between legumes and grasses in cell wall digestion properties (Van Soest, 1994).

\section{CONCLUSIONS}

The present study based on iNDF kinetics and steady-state rumen models demonstrated that particle breakdown in the rumen is a relatively slow process. Contribution of particle breakdown to turnover of different particle size fractions of 
rumen iNDF decreased with decreasing particle size whereas the contribution of passage increased. Accumulation of iNDF in the rumen was greater than generally observed with grass-based diets and pdNDF was rapidly digested.

\section{REFERENCES}

Ahvenjärvi S., Joki-Tokola E., Vanhatalo A., Jaakkola S., Huhtanen P., 2006. Effects of replacing grass silage with barley silage in dairy cow diets. J. Dairy Sci. 89, 1678-1687

Ahvenjärvi S., Skiba B., Huhtanen P., 2001. Effect of heterogeneous digesta chemical composition on the accuracy of measurements of fiber flow in dairy cows. J. Anim. Sci. 79, 1611-1620

Allen M.S., Mertens D.R., 1988. Evaluating constraints on fiber digestion by rumen microbes. J. Nutr. 118, 261-270

Beauchemin K.A., Buchanan-Smith J.G., 1989. Effects of dietary neutral detergent fiber concentration and supplementary long hay on chewing activities and milk production of dairy cows. J. Dairy Sci. 72, 2288-2300

Bosch M.W., Bruining M., 1995. Passage rate and total clearance rate from the rumen of cows fed on grass silages differing in cell-wall content. Brit. J. Nutr. 73, 41-49

Bosch M.W., Lammers-Wienhoven S.C.W., Bangma G.A., Boer H., Van Adrichem P.W.M., 1992. Influence of stage of maturity of grass silages on digestion processes in dairy cows. 2. Rumen contents, passage rates, distribution of rumen and faecal particles and mastication activity. Livest. Prod. Sci. 32, 265-281

Bruining M., Bakker R., Bruchem J.V., Tamminga S., 1998. Rumen digesta kinetics in dairy cows fed grass, maize and alfalfa silage. 1. Comparison of conventional, steady-state and dynamic methods to estimate microbial degradation, comminution and passage of particles. Anim. Feed Sci. Tech. 73, 37-58

Combs D.K., Shaver R.D., Satter L.D., 1992. Retention of rare earths by hay particles following incubation in fresh or autoclaved rumen fluid. J. Dairy Sci. 75, 132-139

Ellis W.C., Matis J.H., Hill T.M., Murphy M.R., 1994. Methodology for estimating digestion and passage kinetics of forages. In: G.C. Fahey (Editor). Forage Quality, Evaluation, and Utilization. University of Nebraska, Lincoln, pp. 682-756

Fisher D.S., Burns J.C., Pond K.R., 1988. Estimation of mean and median particle size of ruminant digesta. J. Dairy Sci. 71, 518-524

Harvatine D.I., Winkler J.E., Devant-Guille M., Firkins J.L., St-Pierre N.R., Oldick B.S., Eastridge M.L., 2002. Whole linted cottonseed as a forage substitute, fiber effectiveness and digestion kinetics. J. Dairy Sci. 85, 1988-1999

Huhtanen P., Ahvenjärvi S., Weisbjerg M.R., Norgaard P., 2006. Digestion and passage of fibre in ruminants. In: K. Sejrsen, T. Hvelplund, M.O. Nielsen (Editors). Ruminant Physiology: Digestion, Metabolism and Impact of Nutrition on Gene Expression, Immunology and Stress. Wageningen Academic Publishers (The Netherlands), pp. 87-135

Huhtanen P., Asikainen U., Arkkila M., Jaakkola S., 2007. Cell wall digestion and passage kinetics estimated by marker and in situ methods or by rumen evacuation in cattle fed hay 2 or 18 times daily. Anim. Feed Sci. Tech. 133, 206-227

Huhtanen P., Hristov A.N., 2001. Estimating passage kinetics using fibre-bound ${ }^{15} \mathrm{~N}$ as an internal marker. Anim. Feed Sci. Tech. 94, 29-41

Huhtanen P., Kukkonen U., 1995. Comparison of methods, markers, sampling sites and models for estimating digesta passage kinetics in cattle fed at two different levels of intake. Anim. Feed Sci. Tech. 52, 141-158 
Khalili H., Huhtanen P., 2002. Effect of casein infusion in the rumen, duodenum or both sites on factors affecting forage intake and performance of dairy cows fed red clover-grass silage. J. Dairy Sci. 85, 909-918

Kuoppala K., Ahvenjärvi S., Rinne M., Vanhatalo A., 2005. NDF digestion in dairy cows fed grass or red clover silages cut at two stages of growth. In: R.S. Park, M.D. Stronge (Editors). Silage Production and Utilization: Proceedings of the XIVth International Silage Conference; a Satellite Workshop of the XXth International Grassland Congress. Belfast (Northern Ireland). Wageningen, Academic Publishers, p. 164

Legay-Carmier F., Bauchart D., 1989. Distribution of bacteria in the rumen contents of dairy cows given a diet supplemented with soya-bean oil. Brit. J. Nutr. 61, 725-740

Lund P., 2002. The effects of forage type on passage kinetics and digestibility of fibre in dairy cows. $\mathrm{PhD}$. Thesis. 603 The Royal Veterinary and Agricultural University, Copenhagen

Lund P., Weisbjerg M.R., Hvelplund T., 2007. Digestible NDF is selectively retained in the rumen of dairy cows compared to indigestible NDF. Anim. Feed Sci. Tech. 134, 1-17

Mertens D.R., 1993. Kinetics of cell wall digestion and passage in ruminants. In: H.G. Jung, D.R. Burton, R.D. Hatfield, J. Ralph (Editors). Forage Cell Wall Structure and Digestibility. Amer. Soc. Agron.-Crop Sci., Amer. Soil Sci. Soc. Madison, WI, pp. 535-570

Minson D.J., 1966. The apparent retention of food in the reticulorumen at two levels of feeding by means of a purely feeding technique. Brit. J. Nutr. 20, 765-773

Oshita T., Nonaka K., Kume S., Nakui T., 2004. Effects of forage type on particle size distribution of ruminal digesta and faeces of non-lactating cows fed high quality forage. Livest. Prod. Sci. 91, 107-115

Owens F.N., Hanson C.F., 1992. External and internal markers for appraising site and extent of digestion in ruminants. J. Dairy Sci. 75, 2605-2617

Poppi D.P., Ellis W.C., Matis J.H., Lascano C.E., 2001. Marker concentration patterns of labelled leaf and stem particles in the rumen of cattle grazing bermuda grass (Cynodon dactylon) analysed by reference to a raft model. Brit. J. Nutr. 85, 553-563

Poppi D.P., Norton B.W., Minson D.J., Hendrichsen R.E., 1980. The validity of the critical size theory for particle leaving the rumen. J. Agr. Sci. 94, 275-280

Prigge E.C., Fox J.T., Jacquemet N.A., Russell R.W., 1993. Influence of forage species and diet particle size on the passage of digesta and nylon particles from the reticulorumen of steers. J. Anim. Sci. 71, 2760-2769

Ramanzin M., Bittante G., Bailoni L., 1991. Evaluation of different chromium-mordanted wheat straws for passage rate studies. J. Dairy Sci. 74, 2989-2996

Rinne M., Huhtanen P., Jaakkola S., 2002. Digestive processes of dairy cows fed silages harvested at four stages of grass maturity. J. Anim. Sci. 80, 1986-1998

SAS, 2003. User's Guide: Statistics, Version 9.1 Edition. SAS Institute Inc. Cary, NC

Shaver R.D., Nytes A.J., Satter L.D., Jorgensen N.A., 1988. Influence of feed intake, forage physical form, and forage fiber content on particle size of masticated forage, ruminal digesta, and faeces of dairy cows. J. Dairy Sci. 71, 1566-1572

Siddons R.C., Paradine J., Beever D.E., Cornell P.R., 1985. Ytterbium acetate as a particulate-phase digesta-flow marker. Brit. J. Nutr. 54, 509-519

Sutherland T.M., 1988. Particle separation in the forestomach of sheep. In: A. Dobson, M.J. Dobson (Editors). Aspects of Digestive Physiology in Ruminants. Cornell University Press, Ithaca, NY, pp. $43-73$

Tamminga S., 1993. Influence of feeding management on ruminant fiber digestibility. In: H.G., Jung D.R., Buxton R.D., Hatfield J., Ralph (Editors). Forage Cell Wall Structure and Digestibility. Amer. Soc. Agron.-Crop Sci., Amer. Soil Sci. Soc., Madison, WI, pp. 571-602 
Tamminga S., Robinson P.H., Vogt M., Boer H., 1989. Rumen ingesta kinetics of cell wall components in dairy cows. Anim. Feed Sci. Tech. 25, 89-98

Udén P., Colucci P.E., Van Soest P.J., 1980. Investigation of chromium, cerium and cobalt as markers in digesta rate of passage studies. J. Sci. Food Agr. 31, 625-632

Ulyatt M.J., Dellow D.W., John A., Reid C.S.W., Waghorn G.C., 1986. Contribution of chewing during eating and rumination to the clearance of digesta from the ruminoreticulum. In: L.P. Milligan, W.L. Grovum, A. Dorbson (Editors). Control of Digestion and Metabolism in Ruminants. Englewood Cliffs, NJ, pp. 498-515

Van Soest P.J., 1994. Nutritional Ecology of the Ruminant. Second Edition. Cornell University Press, Ithaca, NY, pp. 476

Van Soest P.J., Robertson J.B., Lewis B.A., 1991. Methods for dietary fiber, neutral detergent fiber and nonstarch polysaccharides in relation to animal nutrition. J. Dairy Sci. 74, 3583-3597 